\title{
Investigation of the Factors Influencing Family Functions Style
}

\author{
Ayfer Aydıner Boylu', Zeynep Çopur ${ }^{\mathrm{i}}$, Hülya Öztop ${ }^{\mathrm{c}}$ \\ ${ }^{a}$ Assoc. Prof. Hacettepe University, Faculty of Economics and Administrative Sciences, Department of Family and Consumer Sciences, 06800 \\ Beytepe Ankara/TURKEY \\ ${ }^{b}$ Assoc. Prof. Hacettepe University, Faculty of Economics and Administrative Sciences, Department of Family and Consumer Sciences, 06800 \\ Beytepe Ankara/TURKEY \\ ${ }^{c}$ Assoc. Prof. Hacettepe University, Faculty of Economics and Administrative Sciences, Department of Family and Consumer Sciences, 06800
} Beytepe Ankara/TURKEY

\begin{abstract}
The purpose of this study is to explore the factors which affect the family functions. Participants of this study consisted of married employees with children at the Hacettepe University in Ankara, Turkey. The sample size is determined using a random sampling method $(\mathrm{n}=551)$. In this research, family functioning style scale, support functions scale, and family needs scale developed by Dunst, Trivette and Deal (1988) used as well as the socioeconomic data such as age, gender, level of education, number of children, and the income level. According to the results of the study, married employees could be characterized as experiencing upper moderate family strengths and capabilities. Results of means comparisons showed significant differences on the family functioning style level by various socioeconomic factors. Higher levels of education, working less hours per week, having working spouse positively related to family functioning style. However, having 19 or older age children negatively related to family functioning style. Also age, number of children, and family size were negatively, but income was positively correlated to family functioning style. Regression analysis results suggested significant relationships exist among emotional support and agency support and family functioning style when controlling for socioeconomic variables.
\end{abstract}

Key Words: family, family functions, family needs, family support.

\section{(C) 2013 Published by SSBFNET}

\section{Introduction}

Family, which is regarded as the smallest essential unit of society, has an inevitable significance for human life. Family is the first environment for an individual to satisfy his/her needs to achieve satisfaction from life, to carry out her functions and to grow up as a socially proper person (Bulut, 1990). There exist functional needs that are basic duties aimed at performing certain functions for familial needs. These functional needs cannot be satisfied without certain support mechanisms and a style of functioning approved by family members (Bray, 1995; Özgüven, 2001).

${ }^{\mathrm{i}}$ Corresponding Author Phone: 90 (312) $2976350 / 366$ 
Although the institution of family has continued to be universal throughout the human history, its dimensions and content undergo certain transformations in response to social changes (Sanay, 1990; Sabatelli and Bartle, 1995). The process of social change alters the functions of family depending on the social structure in general and on the characteristics of the family in particular such as the socioeconomic level and the place of settlement (Bulut, 1993). Although certain characteristics of the family change as a result of this transformation, it retains several peculiar features and functions (Şimşek, 2009). Its main functions that are more or less similar in all societies are the following: continuing the bloodline, satisfying economic needs, providing status, planning children's education, socialization and care of children, performing spare time activities, protection of family members, creation of environment of mutual love, division of roles within the family and mutual satisfaction (Ogburn, 1963; Yorburg, 1983). All these functions can be grouped under four main categories as "biological", "social", "psychological" and "economic" (Yıldız, 1997; Sanay, 1990; Özgüven, 2001).

It is possible for people to become healthy individuals if they healthily carry out the functions of their families (Bulut, 1993). Although there does not exist a consensus on the definition and characteristics of healthy family, those families that successfully perform familial functions and provide satisfaction to their members are called healthy families. In a healthy family structure, members are cordial to each other, they react emotionally and exhibit necessary love and care, and emerging problems are resolved without damaging the unity of the family. Flexibility is inherent to the internal structure and functioning of a healthy family. There exists a healthy communication among its members. Children are informed in every issue that matters for the family. No side is taken in case of a conflict. Unconditional love is pertinent in such a family. Other than the common life of the family, every member has different engagements and relationships. In a healthy family, members define the existing interaction as "togetherness" and the needs, skills and powers of each member are taken into consideration. For this reason, the decisions made in this family are based not on coercion but on rationality (Duyan, 2000; Kabasakal, 2001; Nazli, 2003).

The number of studies conducted on this issue is low, and the factors influencing family functions are also understudies in the literature. Therefore, this study aims to examine the impacts of familial needs and family support functions on the functioning style of families when controlling for socioeconomic characteristics. It is expected in this study to find a correlation between family functions and family needs, family support, and socioeconomic characteristics of family. However, no study was found in the literature that examined this relationship directly through the functioning type of family, family needs and support functions. In this respect, this research is original in that it is the first study that investigates this relationship in Turkey. Some studies were found in the literature that examined the relationship between family functions and socioeconomic characteristics of family with respect to some though not all of them.

Lewis et al. (1976) define those families that fulfill their functions to the expected degree as functional families, and those that fail to fulfill their functions due to the lack of internal communication as non-functional families. When considered together, the functional family can be called "healthy" whereas the non-functional one can be labeled as "unhealthy" family (Bulut, 1993). When problematic processes regarding individuals prompt the family, a healthily functioning family can cope with the problem by providing necessary changes suitable to this new situation (Epstein et al., 1993). A non-functional family, on the other hand, cannot overcome problems and thus the existing problems within the family persist in different guises (Becvar and Becvar, 1982).

"Health" of a family is contingent upon its socioeconomic condition, services and facilities available in the society, members' personalities and domestic relationships (Bulut, 1993). In addition, some other factors are also influential directly or indirectly; such as gender, age, educational level, number of members, number of children, family type, presence of members who have chronic disease or disabilities, and the life cycle of the family (Bilen, 2004; Duyan, 2000; Bulut, 1993; Gökçe, 1990).

\section{Literature Review}

Studies on family functions demonstrated the relationships between the presence of family members who have mental or chronic disease, disability or substance addiction and family functions. Studies also focus on the functions of families that have children with special needs (such as a child with a learning disability, conduct disorder, child with functional motor limitations), adolescent children or adopted children. Moreover, among other issues covered are the relationship between family functions and pregnancy, age of being parents and socioeconomic level; and the impacts of family functions on sibling relations (Ahmeduzzaman \&Roopnarine, 1992; Slee, 1996; McGrath, 1997; Hossain, 2001; Gallo \&Szychlinski, 2003; Massatti, Vonk\&Gregoire, 2004; Prrıla et. al, 2005; Prrla, 2006; Wilkins, 2007; 
Orme et al., 2007; Nalavany, Ryan \& Hinterlong, 2009; Nalavany, Glidden \& Ryan, 2009; Al-Krenavi, Graham \& Gharaibeh, 2011; Keklikoglou et. al., 2012; Leung \& Shek, 2013).

Studies have looked at the relationship between gender and family functions, Krasnow's (1995) study found no significant correlation, whereas in the study carried out by Hossain (2001) to examine the division of household labor and family functioning of mothers and fathers, Navajo mothers reported greater commitment, cohesion, and communication in the family than fathers. Nonetheless, mothers and fathers reported similar perceptions in some areas of family functioning, such as coping and competence. Similarly Sylvanus's (1992) research found higher scores on the Family Functions Style Scale for women when compared to men.

Earlier studies found a positive correlation between the functions of the family and income level (Krasnow, 1995; Nazlı, 1997; Hayden et al., 1998; Duyan, 2000; Sertelin, 2003; Çakıcı, 2006, Şimşek, 2009). In the study carried out by Inci (2008), who examined domestic functions with respect to professional groups, and the study conducted by Çakıcı (2006), who investigated the family functions and the impacts of these functions on mother-child relations in families from lower and higher socioeconomic status that had children at the age of six; it was found that family functions differ significantly between socioeconomic status, and families with higher socioeconomic status were found less healthy in terms of general functions. Similarly, in the study carried out by Fişek (1992) families with higher socioeconomic status were faced with a structural problem. That is, although these families did not have symptomatic complaints, they exhibited an excessive ambiguity in relations of authority, power and status; alterations in family functions and a rapid change.

In a study that examined the relationship between family functions and ages of females and males, while no significant correlation was found with respect to females' ages, the difference was found to be significant with respect to males' ages (Çakıc1, 2006). Studies found a positive correlation between males' educational attainment and general functions (Nazlı, 1997; Duyan, 2000; Çakıcı, 2006, Şimşek, 2009). Although women's educational attainment was understudies, a positive correlation was found between functions and women's educational attainment in one study (Çakıc1, 2006). According to Krasnow's (1995) research, in terms of family functions there were no significant differences patterns of strengths reported by parents employed full-time and part-time.

The study performed by Hayden et al. (1998), the average differences with respect to family functions was investigated between families whose heads were married couples and unmarried mothers, family functions were found to be significantly lower in families where the head is unmarried mother than families whose heads were married couples. However, Krasnow (1995)found that, in terms of family functions there were no significant differences patterns of strengths reported by married and single (including divorced) parents. Yet another common finding in studies is that employed women carry out family functions more healthily when compared to unemployed women (Nazlı, 1997; İmamoğlu, 1991).

In studies that examined the relationship between family functions and the number of children, no correlation was found (Sertelin, 2003; Çakıc1, 2006). In İnci's (2008) study, a positive correlation was observed between the number of members and the family's general functions. However, Çakıcı (2006) found that no such correlation. Studies demonstrated that a difference in functions exists with respect to the type of family and it is concluded that nuclear families functions better than others functions (Nazlı, 1997; İmamoğlu, 1991). It was observed in traditional family types that couples live in almost different worlds, that is, they do not talk much about issues such as children's growth, private emotions and thoughts, sexual life and health problems, social relations and politics. The communication between couples is higher in nuclear families and they know more about each other's emotions, ideas and social circles. In this research, Family Functioning Style Scale was employed as the dependent variable, and thus the impacts of family needs and family support functions on family functions when controlling for socioeconomic characteristics were investigated.

\section{Methodology}

\section{Data and Sample}

Participants of this study consisted of employees at the central campus and Beytepe campus of Hacettepe University, Ankara. A complete list of employees (academic, administrative, technical, health/assistant health, and maintenance staff) was obtained from the Human Resources Office (HRO) of the university. The lists included names, area of 
employment, and some demographic and contact information. This research focuses on family functioning of individuals who are married and have children. According to HRO' lists; the total population of married staff at Hacettepe University's was 6449. The sample size was determined according to the Random Sampling Method and $\mathrm{n}=551$ was found (administrative staff $=57.9 \%$, academic staff $=13.6 \%$, maintenance staff $=20.3 \%$, technical staff $=7.4$ $\%$, and health/assistant health staff $=7.0 \%$ ). Random number tables were used to select the participants.

Participants were contacted in person and surveys were given individually. Upon arrival at their work sites, and following the researcher's self-introduction, the purpose of the study was explained. Participants were also informed that participation in the study was voluntary. After obtaining their consent, the survey packets, which subjects read and completed on their own, were distributed, and then researchers collected all surveysonce they were completed. None of the contacted individuals refused to participate. Data were collected June 2010.

The majority $(64.6 \%)$ of the sample was men, $35.4 \%$ were women. The ages of the participants ranged from $23-65$ years $(M=39.76$ years, $S D=6.98)$. More than half of were college or more degree $(57.0 \%)$ and $43.0 \%$ had high school or less graduates. Majority of were working 36-44 hours/week with a $99.1 \%$ working full-time. With respect to the spouses of those interviewed, $58.3 \%$ working, 38.8\% does not work, and $2.9 \%$ were retired. Examination of data revealed that most of them (88.4\%) lived in nuclear families; and $82.4 \%$ of them had 1 or 2 children; and $36.3 \%$ of the sample has 0-5 years old, 51.7\% 6-11 years old, 38.8\% 12-18 years old, 20.7\% 19 or more years old child. The participant's monthly income was obtained via an open-ended item and the mean monthly income was determined to be 2,550 TL ( 1 U.S. dollar is equivalent to about 1.58 TL in 2010)

Tabel 1. Description of the Sample

\begin{tabular}{lll}
\hline Socioeconomic characteristics & & $\%$ \\
\hline \multirow{2}{*}{ Gender } & Women & 35.4 \\
& Men & 64.6 \\
Education & High school or less & 43.0 \\
& More than high school & 57.0 \\
Family type & Nuclear & 88.4 \\
& Other & 11.6 \\
Working hours & 35 or less hrs/wk & 18.7 \\
& $36-44$ hrs/wk & 67.3 \\
Spouse working status & 45 or more hrs/wk & 14.0 \\
& Not working & 38.8 \\
& Working & 58.3 \\
Age of Childs & Retired & 2.9 \\
& $0-5$ age child & 36.3 \\
& $6-11$ age child & 51.7 \\
Age & $12-18$ age child & 38.8 \\
Income & 19 or more age child & 20.7 \\
Number of child & Mean & $\mathbf{S D}$ \\
Family size & 39.8 (23-65) & 6.98 \\
\hline
\end{tabular}

Source: This Study

\section{Measurement of Variables}

\subsection{Independent Variables}

Socioeconomic variables: This study involved information about the participants' personal characteristics such as age, gender, participants' level of education, working status, spouse' working status, working hours per week, number of 
children, age of children, family type, family size and household's monthly income. These characteristics were selected according to the research literature and their potential effects on the results. Descriptive statistics on dependent variables are clustered according to personal characteristics.

Family Needs Scale: The Family Needs Scale measures participant's need for different kinds of resources and support such as "having food for two meals for my family". The scale includes 41 items organized into nine categories of needs (financial, food and shelter, vocation, child care, transportation, communication, etc.). The items of the family needs developed by Dunst, Trivette, and Deal (1988)were utilized for the scale. Each item is rated on a 5-point scale ranging from almost never (1) to almost always (5) a need. If item was not applicable participants indicate as NA. All items were coded so that lower scores reflect lower levels of family needs and higher scores reflect higher levels of family needs. Scores on the family needs scale were computed by adding numerical responses for each of forty one items, then dividing the total by forty one. Resulting scores could range from 1 to 5 (highest levels of meet the needs). The average mean family needs scale score for Turkish sample was $2.83(S D=.95)$, which indicated that upper moderate levels of meet needs.

The maximum likelihood confirmatory factor analysis performed for validity analysis to Family Needs Scale using the LISREL 8.80 program. However, higher order factor analysis performed due to high correlation among the factors. Goodness- of-fit indices $\square \square\left(\chi^{2}=3.04, d f=3, \mathrm{GFI}=1.00, \mathrm{CFI}=1.00, \mathrm{NFI}=1.00, \mathrm{NNFI}=1.00, \mathrm{AGFI}=.99, \mathrm{RMSEA}=.004\right)$ suggest that the 1-factor model has an excellent fit for Turkish sample.Depending on the outcome of the scale total score was used. In addition, because of the auto-correlation between factor 1 and factor 2 and factor 3 and factor 5, error variances released. Cronbach alpha internal consistency reliability was calculated to be .97 . These results can be accepted as proof for the validity and reliability of the items, and thus, of the scale.

Support Functions Scale: We used the Turkish version of support functions scale developed by Dunst, Trivette and Deal (1988) to measure parents' needs for different types of help and assistance. The parents were asked to indicate all of the things that others did that they found helpful and supportive. Taxonomy of needs was generated from their responses, and the resources named most frequently were selected for inclusion in the scale. If a source of help has not been available to family participants indicate as NA (Not Available). This scale, which was measured on a 5-point scale ( $1=$ never need this type of support and $5=$ quite often need this type of support), consisted 20 items such as "my relatives/kin". All items were coded so that a higher score indicated more support and less need for help. The average mean support functions scale score for Turkish sample was $2.91(S D=.73)$, which indicated that upper moderate levels of support.

The maximum likelihood confirmatory factor analysis performed for Support Functions Scale using the LISREL 8.80 program. Goodness-of-fit indices $\square \square\left(\chi^{2}=570.14, d f=140, \mathrm{GFI}=.90, \mathrm{CFI}=.97, \mathrm{NFI}=.95, \mathrm{NNFI}=.96, \mathrm{AGFI}=.86\right.$, RMSEA=.078) suggest that the 5-factor model has an excellent fit for Turkish sample.But the Turkish version of the scale in the 4 item (talk with you about child-rearing problems) was observed to be loaded with more than one dimension and it take from the scale. In addition, because auto-correlation between item 2 and 12, and item 14 and 16 that measure same dimension, the error variance was released. It can be noted with the validity and reliability.

Factor I included nearly all the Emotional Support items (someone to talk to, someone to encourage you, someone to talk to about child-rearing concerns, etc.); Factor II included five Child Support items (cares for child regularly or in emergencies, interacts with and accepts child, procures services for child); Factor III included the Financial Support items (lends you money, provides money for basic needs); Factor IV included four Instrumental Support items (fixes things around the house, does household chores, etc.); and Factor V included two items measuring Agency Support (obtains services for child). The factor analysis results indicate that a person's perceived need for support is multidimensional in nature and that there are clearly discernible types of needs categories. Cronbach alpha internal consistency reliability was calculated to be .84 for first factor, .84 for second factor, .67 for third factor, .74 for fourth factor, .64 for fifth factor and Coefficient alpha computed from the average correlation among the 19 scale items was .91 .

\subsection{Dependent Variable}

Family Functioning Style Scale: We used the Turkish version of family functioning style scale developed by Dunst, Trivette, and Deal (1988)to measure family functioning of the participants. The Family Functioning Style Scale (FFSS) includes 26 items that assess various kinds of family strengths and capabilities. The instrument was developed as part of a family-centered assessment and intervention model that has evolved from efforts to intervene in ways that support 
and strengthen family functioning. The scale assesses the extent to which an individual family member, or two or more family members completing the scale together, believes their family is characterized by different strengths and capabilities. In the current study individual family member completed the scale. This scale, which was measured on a 5-point Likert Scale $(1=$ not at all like my family and $5=$ almost always like my family), consisted of five factor. The first factor includes items that measure the interactional patterns of the family (e.g., not taking each other for granted, spending time together, listening to all points of view, and sharing concerns and feelings). The second factor includes items that assess family values, including taking pride in accomplishments of family members, making personal sacrifices for the benefit of the family, and believing that family relationships are more important than material possessions. The third factor includes items that reflect intrafamily coping strategies, including looking for the bright side of things, not worrying about uncontrollable events, trying to forget overwhelming problems, and believing there is good even in the worst situations. The fourth factor, family commitment, includes items such as making decisions that benefit the whole family, depending on other family members, and trying to solve problems within the family first before asking for outside help. The fifth factor, resource mobilization, includes two items that tap extra family support utilization. Taken together, the factor analysis results indicate that the types of family strengths and capabilities measured by the FFSS are multidimensional in nature.

In the original scale the alpha reliability is .92 . Validity and reliability tests for the scale have also been carried out in Turkish sample, where it has been to be statistically appropriate for use in data collection. Similar to original scale, Principal Component Factor Analysis with an oblique rotation was used for validity analysis to determine model fit between US and Turkey. Oblique rather than an orthogonal rotation was used because it was expected that the different strengths of families would be interrelated (Dunst, Trivette, and Deal, 1988). A factor loading of .35 or higher was used to establish factor membership. The analysis produced five interpretable factor solutions accounting for $55 \%$ of the variance. The maximum likelihood confirmatory factor analysis also performed for FFSS using the LISREL 8.80 program. Goodness-of-fit indices $\square \square\left(\chi^{2}=861.20, d f=289\right.$, GFI=.89, CFI=.96, NFI=.93, NNFI=.95, AGFI=.87, RMSEA=.061) suggest that the 5-factor model has an excellent fit for Turkish sample. These results can be accepted as proof for the validity of the items, and thus, of the scale. Findings demonstrated, as in the original scale that different strengths of a family are interrelated and thus the total score of the scale was used in analyses. However, some items were swapped over while the number of dimensions remained the same. Whereas the items 5, 8,9 and 13 were placed in the $1^{\text {st }}$ dimension in the original scale; we placed them in the $2^{\text {nd }}$ dimension. We also changed the locations of the items 21 and 25 from the $1^{\text {st }}$ to the $4^{\text {th }}$ dimension. The item 3 was moved from the $3^{\text {rd }}$ to the $5^{\text {th }}$, item 14 from the $5^{\text {th }}$ to the $1^{\text {st }}$, and the item 22 was moved from the $2^{\text {nd }}$ to the $4^{\text {th }}$ dimension. Finally, while the original scale did not include the items 2 and 15 ; we put the item 2 in the $2^{\text {nd }}$ dimension and the item 15 in the $4^{\text {th }}$ dimension. This shows that items can be placed in different dimensions depending on the sample. However, since the analysis was performed through the total score, we did not stress too much on these changes.

In order to test the reliability of the measure, Cronbach's Alpha was selected. Cronbach alpha reliabilities for the 26 items was calculated to be $=.89$. This result suggests that the inner consistency of the inventory is high. Individual scores can range from 26 ( 1 point on each question) to 130 (5 points on each question). Scores on the Family Functioning Style were computed by adding numerical responses for each of twenty six items, then dividing the total by twenty six. Resulting scores could range from 1 (lowest family strengths and capabilities) to 5 (highest family strengths and capabilities). The average mean family functioning style score for Turkish sample was $4.18(S D=.45)$, which indicated that high family strengths and capabilities.

\section{Data Analysis}

Data analysis began with calculating frequencies of the sample on all independent variables. Independent sample $t$ tests and Pearson correlation were then used to compare mean values on the family functioning scale by characteristics of the sample. One-way analysis of variance was then computed to compare means among categories of subjects on each categorical variable. When the $F$-test indicated significant (.05) mean differences on a given variable, the Scheffe multiple comparison test was used to isolate the specific between-category means that were significantly different. Then independent sample $t$-tests were then used to compare mean values on the family functioning sub-scale and all items by gender. Finally, Ordinal Least Square Regression Analysis was computed to determine the interrelationships between family functioning and the independent variables. Variables were entered into the regression equation in the following order: socioeconomic variables, family needs and family support functioning variables. For the regressions, some dummy variables had to be created. Gender was already coded as a dummy variable with female $=1$ and male $=0$ with female as the reference category. Age, number of child, family size and income were continuously measured in 
years, number and Turkish lira, respectively. Educational level was re-coded from seven items (primary school, secondary school, high school, college, master's degree, and doctoral degree) into two categories as high school graduates or less $=0$, and college graduates or more $=1$. Family type, which initially was comprised of four categories ( $1=$ nuclear, $2=$ extended family, $3=$ single parent family, $4=$ other $)$, was collapsed into nuclear $=1$ and others $=0$. Family life stage was re-coded as beginning and contracting $=0$ or expanding $=1$. Finally, number of children was re-coded as none $=0$ and 1 or more children $=1$. Before running regression, data were checked for assumption of regression analysis (multi-colinearity and autocorrelation) and were found fit for the procedure. We are expecting there is relationship between family functioning style and family needs and support functions when controlling socioeconomic variables.

\section{Findings}

\subsection{Bivariate Results}

\section{Participants' Family Functioning Style by Socioeconomic Characteristics}

Table 2 summarizes the comparison of participants' family functioning style. The averages for the scale are listed for socioeconomic characteristics. Results of the bivariate analysis test showed that participants' family functioning style score differed by their socioeconomic characteristics. As can be seen in Table 2, women $(M=3.22)$ had significantly higher family functioning style score than men $(M=3.16)$. However, between women and men, there is no significant differences on family functioning style $(p>.05)$. Participants' level of education was significantly related to family functioning style. The family functioning style score was higher for the high school or more educational level $(M=$ 3.22) $(p<.05)$. Table 2 also shows the results of one-way ANOVA for work hours, where the means of working hours was significant $(F=7.55, p<.001)$. For those variables showing significant differences, the Scheffe Multiple Comparison Test was used to determine which pairs of categories of each variable were significantly different (Table 2). An interesting pattern in working hours showed that participants' who works 35 or less hours per week $(M=3.33)$ reported higher scores of family functioning style than participants' who works 36 or more hours per week.

As can be seen in Table 2, family functioning style was significantly different by working status of participants' spouse. Participants' who has working spouse $(M=3.25)$ had higher levels of family functioning style than those who has retired or not working spouse. Number of children and age of children were also significantly related to family functioning style. Number of children was negatively related to family functioning scale. This indicates that participants who have fewer children reported higher score on family functioning style. Also participants who have 19 or more age of children were significantly related to family functioning style. Participants' income also was significantly related to family functioning style. However, participants' age and family size were negatively related to family functioning style. 
Tabel 2. Bivariate Analysis Results of Family Functioning Style Scale Averages

Score According to Sample Characteristics

\begin{tabular}{|c|c|c|c|}
\hline Socioeconomic characteristics & Mean & $S D$ & $\begin{array}{c}\text { Test } \\
\text { Statistics }\end{array}$ \\
\hline \multicolumn{4}{|l|}{ Gender } \\
\hline Women & 3.22 & .43 & $t=1.63$ \\
\hline Men & 3.16 & .46 & \\
\hline \multicolumn{4}{|l|}{ Levels of Education } \\
\hline High school or less & 3.13 & .51 & $t=-2.19^{*}$ \\
\hline More than high school & 3.22 & .40 & \\
\hline \multicolumn{4}{|l|}{ Family type } \\
\hline Nuclear & 3.19 & .44 & $t=1.81$ \\
\hline Other & 3.08 & .54 & \\
\hline \multicolumn{4}{|l|}{ Working hours per week } \\
\hline 35 or less hrs/wk & 3.33 & .45 & $F=7.55^{* * *}$ \\
\hline $36-44 \mathrm{hrs} / \mathrm{wk}$ & 3.14 & .43 & \\
\hline 45 or more hrs/wk & 3.18 & .49 & \\
\hline \multicolumn{4}{|l|}{ Spouse working status } \\
\hline Not working & 3.08 & .49 & $F=9.18^{* * *}$ \\
\hline Working & 3.25 & .41 & \\
\hline Retired & 3.08 & .42 & \\
\hline \multicolumn{4}{|l|}{ Age of Childs } \\
\hline $0-5$ age child & 3.22 & .44 & $t=1.59$ \\
\hline 6-11 age child & 3.18 & .40 & $t=.21$ \\
\hline 12-18 age child & 3.15 & .44 & $t=-1.19$ \\
\hline 19 or more age child & 3.08 & .51 & $t=-2.73 * *$ \\
\hline Age & & & $-.089 *$ \\
\hline Income & & & $.084 *$ \\
\hline Number of child & & & $-.121^{* *}$ \\
\hline Family size & & & $-.106^{*}$ \\
\hline
\end{tabular}

${ }^{*} p<.05, * * p<.01, * * * p<.001$

\section{Comparing Participants' Family Functioning Style Scale by Gender}

A comparison of the FFSS, for both the individual items and combined indices, is summarized in Table 3 . The averages for specific items are listed the total samples and for men and women, along with the averages for the combined indices. Overall, women have more FFSS compared to men, on each item separately and the combined indices. A mean comparison of the combined indices revealed that both men and women experienced higher family commitment factor than other factors.

With regard to interactional patterns of the family in general, an exception was the statement that, "We enjoy time together even if it is doing household chores" women reported higher score than men on all of the items and the overall index, though there were no significant gender difference. Again, with regard to assess family values, an exception was the statement that, "We are always willing to "pitch in" and help each other" women reported higher score than men on the overall index and all items, the significant difference between women and men was on the 
statement "We usually agree about how family members should behave" There was no significant gender difference on other items.

On intra familycoping strategies, an exception was the statement that, "We try to look "at the bright side of things" no matter what happens in our family" women reported higher levels of score than men on all of the items and the overall index, there were no statistically significant gender differences between men and women.

With regard to family commitment, an exception was the statement that, "Our family's relationship will outlast our material possessions" again women reported higher score than men on the overall index and all items, however there was significant difference between women and men on the statement "We try not to take each other for granted". Again with regard to resource mobilization, women reported significantly higher score conflict than men on the overall index and all items.

Among Turkish women, the lower levels of score with the statement, "We try to forget our problems or concerns for a while when they seem overwhelming" (with averages of 3.68 points out of 5) related to lower levels of intra family coping strategies subscale, and among Turkish men, the lower levels of score with the statements, "Friends and relatives are always willing to help whenever we have a problem or critics" related to lower levels of interactional patterns subscale and "We try to forget our problems or concerns for a while when they seem overwhelming" related to lower levels of interactional patterns subscale (with averages of 3.65 points out of 5) similar to women participants. The largest difference between samples was on the statement, "We believe that something good always comes out of even the worst situations" related to resource mobilization, Turkish women reported much higher score with this statement than men. 
Tabel 3. Exposure to Family Functioning Style Topics by Gender

\begin{tabular}{|c|c|c|c|}
\hline \multirow[b]{2}{*}{ Variables } & \multicolumn{3}{|c|}{ Mean (standard deviation) } \\
\hline & $\begin{array}{c}\text { Men } \\
(n=356)\end{array}$ & $\begin{array}{l}\text { Women } \\
(n=195)\end{array}$ & Total \\
\hline Interactional patterns & $3.94(.65)$ & $4.02(.59)$ & $3.97(.63)$ \\
\hline 12. We find time to be together even with our busy schedules & $4.00(.93)$ & $4.14(.84)$ & $4.05(.90)$ \\
\hline $\begin{array}{l}\text { 14. Friends and relatives are always willing to help whenever we have a problem or } \\
\text { crisis }\end{array}$ & $3.65(1.06)$ & $3.72(1.03)$ & $3.68(1.05)$ \\
\hline 16. We enjoy time together even if it is doing household chores & $3.76(1.09)$ & $3.75(1.10)$ & $3.76(1.09)$ \\
\hline 18. Family members listen to "both sides of the story" during a disagreement & $4.13(.92)$ & $4.21(.91)$ & $4.16(.92)$ \\
\hline 19. We make time to get things done that we all agree are important & $4.18(.82)$ & $4.29(.76)$ & $4.22(.80)$ \\
\hline Family values & $4.34(.49)$ & $4.39(.45)$ & $4.36(.48)$ \\
\hline 1. We make personal sacrifices if they help our family & $4.59(.62)$ & $4.65(.58)$ & $4.61(.61)$ \\
\hline 2. We usually agree about how family members should behave & $4.22(.86)^{*}$ & $4.38(.80)$ & $4.27(.84)$ \\
\hline 4. We take pride in even the smallest accomplishments of family members & $4.54(.69)$ & $4.56(.62)$ & $4.55(.67)$ \\
\hline 5. We share our concerns and feelings in useful ways & $4.21(.82)$ & $4.27(.86)$ & $4.23(.83)$ \\
\hline 6. Our family sticks together no matter how difficult things get & $4.45(.76)$ & $4.50(70)$ & $4.47(.74)$ \\
\hline 8. We usually agree about the things that are important to our family & $4.26(.85)$ & $4.30(.72)$ & $4.27(.80)$ \\
\hline 9. We are always willing to "pitch in" and help each other & $4.24(.80)$ & $4.19(.83)$ & $4.23(.81)$ \\
\hline 13. Everyone in our family understands the "rules" about acceptable ways to act & $4.19(.79)$ & $4.20(.83)$ & $4.17(.80)$ \\
\hline 20. We can depend on the support of each other whenever something goes wrong & $4.36(.74)$ & $4.41(.74)$ & $4.38(.74)$ \\
\hline Coping strategies & $3.80(.75)$ & $3.80(.78)$ & $3.80(.76)$ \\
\hline $\begin{array}{l}\text { 10. We find things to do that keep our minds off our worries when something } \\
\text { upsetting is beyond our control }\end{array}$ & $3.76(1.03)$ & $3.79(1.03)$ & $3.77(1.03)$ \\
\hline 11. We try to look "at the bright side of things" no matter what happens in our family & $4.00(.87)$ & $3.92(.88)$ & $3.98(.87)$ \\
\hline $\begin{array}{l}\text { 17. We try to forget our problems or concerns for a while when they seem } \\
\text { overwhelming }\end{array}$ & $3.65(1.03)$ & $3.68(1.07)$ & $3.66(1.04)$ \\
\hline Family commitment & $4.35(.52)$ & $4.41(.56)$ & $4.37(.54)$ \\
\hline $\begin{array}{l}\text { 15. Our family is able to make decisions about what to do when we have problems or } \\
\text { concerns }\end{array}$ & $4.23(.74)$ & $4.26(.72)$ & $4.24(.73)$ \\
\hline 21. We usually talk about the different ways we deal with problems and concerns & $4.27(.82)$ & $4.30(.81)$ & $4.28(.82)$ \\
\hline 22. Our family's relationships will outlast our material possessions & $4.55(.73)$ & $4.51(.85)$ & $4.53(.77)$ \\
\hline $\begin{array}{l}\text { 23. We make decisions like moving or changing jobs for the good of all family } \\
\text { members }\end{array}$ & $4.27(.93)$ & $4.38(.88)$ & $4.30(.92)$ \\
\hline 24. We can depend upon each other to help out when something unexpected happens & $4.45(.72)$ & $4.50(.70)$ & $4.47(.71)$ \\
\hline 25. We try not to take each other for granted & $4.24(.91)^{*}$ & $4.39(.82)$ & $4.29(.88)$ \\
\hline 26. We try to solve our problems first before asking others to help & $4.47(.74)$ & $4.54(.75)$ & $4.49(.74)$ \\
\hline Resource mobilization & $3.68(.93)^{* *}$ & $3.93(.82)$ & $3.77(.90)$ \\
\hline 3. We believe that something good always comes out of even the worst situations & $3.90(1.07)^{* *}$ & $4.16(.91)$ & $3.99(1.02)$ \\
\hline $\begin{array}{l}\text { 7. We usually ask for help from persons outside our family if we cannot do things } \\
\text { ourselves }\end{array}$ & $3.46(1.21)^{*}$ & $3.70(1.12)$ & $3.54(1.19)$ \\
\hline
\end{tabular}

Note: Items use a 5-point Likert scale, with higher values indicating positive family functioning style.

$* p<.05, * * p<.01, * * * p<.001$

\subsection{Multivariate Results}

OLS regression analysis was used to examine the relationship between level of participant' family functioning style scale and family needs and support functions, when controlling for socioeconomic characteristics to measure predicting of family functioning style for each independent variables by one by and to see when the significant is changed. Table 4 summarizes the results of OLS regressions predicting family functioning style. As seen in the Table 4, opposite with our expectation family needs was not related to family functioning style (Step 1). On the other side consistent with our expectation there is relationship between support functions and family functioning style. Emotional support was positively related to family functioning style. As seen in the Table 4, emotional support 
contributes to family functioning style through such variables as socioeconomic characteristics. Participants who had higher levels of emotional support reported significantly higher levels of family functioning style. However, participants who had lower levels of financial and agency support reported significantly higher levels of family functioning style (Step 2). Our hypothesis tested in final model, indicates that there is a relationship between participants' family functioning style and family needs and support functions, when controlling for socioeconomic characteristics. Lower levels of working hours per week were positively related to family functioning style. This indicates that participants who work 35 or fewer hours per week reported higher levels of family functioning style than those who work 36-44 hours per week. Also participants whose spouse was working had significantly higher level of family functioning style those whose spouse was not working. When socioeconomic variables were added to the equation, financial support was not significant. These results partially support our hypothesis (Step 3).

Table 4. OLS Regression Result for Family Functioning Style Scale

\begin{tabular}{|c|c|c|c|c|c|c|}
\hline & \multicolumn{6}{|c|}{ Family Functioning Style Scale } \\
\hline & \multicolumn{2}{|l|}{ Step 1} & \multicolumn{2}{|c|}{ Step 2} & \multicolumn{2}{|c|}{ Step 3} \\
\hline & $\mathrm{B}(S D)$ & $\beta$ & $\mathbf{B}(S D)$ & $\beta$ & $\mathbf{B}(S D)$ & $\beta$ \\
\hline Family Needs & $-.005(.020)$ & -.011 & $-.029(.021)$ & -.060 & $-.007(.022)$ & -.015 \\
\hline \multicolumn{7}{|l|}{ Support Functions } \\
\hline Emotional support & & & $.183(.030)$ & $318 * * *$ & $.151(.033)$ & $.263 * * *$ \\
\hline Child support & & & $.039(.026)$ & .093 & $.019(.027)$ & .044 \\
\hline Financial support & & & $-.058(.026)$ & $-.120 *$ & $-.030(.027)$ & -.062 \\
\hline Instrumental support & & & $.016(.029)$ & .032 & $.011(.031)$ & .022 \\
\hline Agency support & & & $-.066(.026)$ & $-.152 *$ & $-.064(.026)$ & $-.147 *$ \\
\hline \multicolumn{7}{|l|}{ Socioeconomic } \\
\hline \multicolumn{7}{|l|}{ Variables } \\
\hline Gender & & & & & $-.079(.048)$ & -.084 \\
\hline Age & & & & & $.002(.004)$ & .035 \\
\hline Education & & & & & $-.005(.045)$ & -.006 \\
\hline Income & & & & & $7.05(.000)$ & .021 \\
\hline 35or less hrs/wk & & & & & $.139(.054)$ & $.120 * *$ \\
\hline 45 or more hrs/wk & & & & & $.049(.056)$ & .038 \\
\hline Spouse working & & & & & $.143(.054)$ & $.156^{* *}$ \\
\hline Spouse retired & & & & & $.064(.119)$ & .024 \\
\hline Nuclear family & & & & & $.110(.081)$ & .078 \\
\hline Family size & & & & & $.017(.049)$ & .036 \\
\hline Children number & & & & & $-.054(.058)$ & -.091 \\
\hline $0-5$ age child & & & & & $.065(.060)$ & .069 \\
\hline 6-11 age child & & & & & $.004(.054)$ & .005 \\
\hline 12-18 age child & & & & & $.013(.054)$ & .014 \\
\hline 19 or more age child & & & & & $-.063(.073)$ & -.057 \\
\hline Constant & $4.194(.060) * * *$ & & $3.849(.088)^{* * *}$ & & $3.611(.263)^{* * *}$ & \\
\hline$F$ & .066 & & $8.939 * * *$ & & $3.880 * * *$ & \\
\hline$R^{2}$ & .000 & & .090 & & .133 & \\
\hline
\end{tabular}

Note: Unstandardized, standardized coefficients are reported, with standard errors in parentheses. ${ }^{*} p<.05, * * p<.01$, $* * * p<.001$

\section{Discussion and Conclusion}

The purpose of this study has been to explore the relationship between family functioning style and family needs and support functions of married employees when controlling for socioeconomic characteristics. The married employees could be characterized as experiencing upper moderate family strengths and capabilities. In the current study, the median score was reported 4.18 (out of 5), indicating they were experiencing higher family functioning style.

The results of this study provide several key insights. Results from means comparisons showed significant differences 
on the family functioning style level by various socioeconomic factors. Higher levels of education, working less hours per week, having working spouse positively related to family functioning style. However, having 19 or older age children negatively related to family functioning style. Also age, number of children, and family size were negatively, but income was positively correlated to family functioning style.

The belief that income level is associated with the functions of the family is a fact that always accepted. Studies also show that the families in higher income, have better health and mental health, have greater longevity, experience fewer stressful life events, and are more successful. Thus they healthily carry out the functions of their families (Diener\&Diener, 2002; Park, Turnbull \& Turnbull III, 2002; Mcloyd, 1990; Lempers, Clark-Lempers, \& Simons, 1989; Kadushin\& Martin, 1981; Straus, Gelles, \& Steinmetz, 1980; Rubin, 1994; Mills, Grasmick, Morgan, \&Wenk, 1992; Pearlin\&Schooler, 1978; Voydanoff, 1984). Moreover studies clearly show that as income level (Nazl1, 1997; Duyan, 2000; Şimşek, 2009) and parents' educational level (Çakıcı,2006; Şimşek, 2009; Nazlı, 1997; Duyan, 2000) increases, families carry out their general functions more healthily and these results is in line with the results of our study.

Overall, this study found that among employees, the highest levels of family functioning style experienced with the family values subscale and the lowest levels of family functioning style experienced with the resource mobilization subscale. Greater family strengths and capabilities were observed among women compared to men.

OLS regression analysis showed that emotional and agency supports were significantly related to family functioning style when controlling for socioeconomic characteristics.Generally, emotional support was positively related to family strengths and capabilities of married employees. Our results suggest that to have emotional support, working less hours and having working spouse contribute to family strengths and capabilities.

An interesting result in this study is that having less agency support such as someone to help gets services for child associate to family strengths and capabilities. That is to say emotional support is important components because these measure the potential of change in family functioning style.

In partially conformity with our hypothesis, socioeconomic characteristics related to family functioning style, through their impact on the support functions. It can be say that, in the current study married employees support functions predicted family functioning style after controlling for selected socioeconomic characteristics. Furthermore, in the full step, married employees' family strengths and capabilities tended to be related to emotional and agency supports, working hours per week, spouse' working status.

The results of this study help to further document the family functioning style of married employees in a developing country like Turkey. Additional studies should measure the FFSS for different socioeconomic households; especially those living in the rural or retired couples. Several limitations must be kept in mind in interpreting these results. The main limitation of the present study is sample structure. The study sample included only employees at single, state university, which limits the generalizability of the results. Hacettepe is one of the most respected universities in Turkey and is located in Ankara, the capital city. Participants were relatively married university employees, who were middle and upper-middle class.

In addition, not all possible determinants of family functioning style were measured in the study, such as happiness, relationship satisfaction, and life quality. Different findings may have been obtained if study carried out nonurban and various labor forces. In the future, more research and different samples will be needed regarding performing family strengths and capabilities so that results can be applied to different work places (government or private sector) in Turkey. Despite these limitations, this study has made several contributions to the family functions literature. Provides unique data and insights on distinct, university based groups which are theoretically play a pivotal role in society in training the next generation of employees. The clarification that emotional support is more important than other supports in influencing family strengths and capabilities of married couples has implications for counselors, educators, and other helping professionals in the field of family functions. The findings of this study would also be of interest to policy makers in Turkey. The present analysis provided some initial findings towards understanding the extent to working men' and women' experience family functioning style in university employee. Organizations need to establish policies and practices that offer support for family demands and that help employees reduce family problems caused by the juggling of home responsibilities. 
Acknowledgement: This study was funded by the Hacettepe University Scientific Research and Development Office

\section{References}

Ahmeduzzaman, M., \& Roopnarine, J. L. (1992). Sociodemographic factors, functioning style, social support and fathers' involvement with preschoolers in African-American intact families. Journal of Marriage and Family, 54 (3), 699-707.

Al-Krenavi, A., Graham, J. R., \& Gharaibeh, F. A. (2011). A Comparison study of psychological, family function marital and satisfactions of polygamous and monogamous woman in Jordan. Community Mental Health Journal, 47 (5), 594-602.

Becvar, R. J. \& Becvar, D. S. (1982). Family development through the life cycle. Systems theory and family therapy. Lanham: University Press of America.

Bilen, M. (2004) Sağllklı insan ilişkileri, Ankara: Anı Yayıncılık.

Bray, H. (1995). Family assessment. Family Relations, 44 (4).

Bulut, I. (1990). Aile Değerlendirme Ölçeği el kitabı, Ankara: Özgüzeliş Matbaası.

Bulut, I. (1993). Ruh sağlı̆̆ının aile işlevlerine etkisi. Ankara: Başbakanlık Kadın ve Sosyal Hizmetler Müsteşarlığı Yayınları, 15.

Çakıcı, S. (2006). Alt ve üst sosyoekonomik düzeydeki ailelerin aile işlevlerinin, anne-çocuk ilişkilerinin ve aile işlevlerinin anne-çocuk ilişskilerine etkisinin incelenmesi. Gazi Üniversitesi Eğitim Bilimleri Enstitüsü Çocuk Gelişimi ve Eğitimi Ana Bilim Dalı yayınlanmamış yüksek lisans tezi. Ankara.

Diener, E., \& Diener, R. B. (2002). Will money increase subjective well-being? Social Indicators Research, 57, 119169.

Dunst, C. J., Trivette, C. M., \& Deal, A. G. (1988). Enabling and empowering families: Principles and guidelines for practice. Cambridge, MA: Brookline Books.

Duyan, G. Ç. (2000). Aile işlevleri ile ailenin sosyal, demografik, ekonomik nitelikleri ve yaşam döngüsü arasındaki iliş̧kiler. Hacettepe Üniversitesi Sosyal Bilimler Enstitüsü Sosyal Hizmet Anabilim Dalı yayınlanmamış yüksek lisans tezi, Ankara.

Epstein, N. B., Bishop, D. S., Ryan, C. E., Miller, I., Keitner, G. (1993). The McMaster Model view of healthy family functioning, normal family processes, F Walsh (Ed), New York: The Guilford Press.

Fişek, G. (1992). Türk ailesinin dinamik ve yapısal özellikleri üzerine düşünceler ve konuya ilişkin bir ön çalışma. Aile Yazıları: Birey Kişilik ve Toplum. Ankara: Başbakanlık Aile Araştırma Kurumu.

Gallo, A. M., \& Szychlinski, C. (2003). Self-perception and family functioning in healthy school-age siblings of children with asthma and diabetes, and healthy children. Journal of Family Nursing, 9(4), 414-434.

Gökçe, B. (1990). Aile ve aile tipleri üzerine bir inceleme, Aile Yazıları 1, T.C. Başbakanlık Aile Araştırma Kurumu Başkanlığı Yayınları, Cilt: 3, Ankara, 1990.

Hayden L. C., Schiller, M., Dickstein, S., Seifer R., Sameroff, A. J., Miller, I., Keitner, G., Rasmussen, S. (1998). Levels of family assessment: I. family, marital, and parent-child interaction. Journal of Family Psychology, 12 (1), 722.

Hossain, Z. (2001). Division of household labor and family functioning in off-reservation Navajo Indian families. Family Relations, 50 (3), 255-261.

İmamoğlu, O. (1991). Aile içinde kadın ve erkek rolleri. Aile Kurultayl. Ankara: Aile Araştırma Kurumu Yayını.

İnci, H. (2008). Meslek gruplarına göre aile içi fonksiyonların araştırılması. Fatih Üniversitesi Tıp Fakültesi Aile Hekimliği Anabilim Dalı yayınlanmamış yüksek lisans tezi, Ankara. 
Kabasakal, H. Z. (2001). Uyum sorunlu çocukların aile işlevlerini iyileş̧tirmede anne eğitim gruplarının etkisi. Dokuz Eylül Üniversitesi Yayımlanmamış Doktora Tezi, İzmir.

Kadushin, A., \& Martin, J. A. (1981). Child abuse: An interactional event. New York: Columbia University Press.

Keklikoglou, I., Koerner, C., Schmidt, C., Zhang, J. D., Heckmann, D., Shavinskaya, A., Allgayer, H., Gückel, B., Fehm, T., Schneeweiss, A., Sahin, Ö., Wiemann, S., \& Tschulena, U. (2012). MicroRNA-520/373 Family functions as a tumor suppressor in estrogen receptor negative breast cancer by targeting NF- $\mathrm{kB}$ and TGF- $\beta$ Signaling Pathways. Oncogene, 31, 4150-4163.

Krasnow, M. (1995). Strength-based family assessments. A paradigm shift utilizing a family functioning scale to identify Strengths. USA: UMI Company.

Lempers, J. D., Clark-Lempers, D., \& Simons R. L. (1989). Economic hardship, parenting, and distress in adolescence. Child Development, 60, 25-39.

Leung, J. T. Y., \& Shek, D. T. L. (2013). Parental Beliefs and Family Functioning in Chinese Families Experiencing Economic Disadvantage in Hong Kong. International Journal on Disability and Human Development, 12 (2), 151161.

Lewis, J.M., Beavers, W. R., Gosselt, J.T., and Philips, V.A. (1976). No single thread: Psychological health in family systems. New York: Brunner/Mazel.

Massatti, R. R., Vonk, M. E., \& Gregoire T. K. (2004). Reliability and validity of the Transracial Adoption Parenting Scale. Research on Social Work Practice, 14 (1), 43-50.

McGrath, M. M. (1997). Estimating risk and protective indexes in high risk children. Clinical Effectiveness in Nursing, 1, 92-104.

Mcloyd, V. (1990). The impact of economic hardship on black families and children. Psychological distress, parenting and socioemotional development. Child Development. 61, 311-346.

Mills, R. J., Grasmick, H. G., Morgan, C. S., \& Wenk, D. A. (1992). The effects of gender, family satisfaction, and economic strain on psychological well-being. Family Relations, 41, 440-445.

Nalavany, B. A., Glidden, L. M., \& Ryan, S. D. (2009). Parental satisfaction in the adoption of children with learning disorders: The role of behavior problems. Family Relations, 58, December, 621-633.

Nalavany, B. A., Ryan, S. D., \& Hinterlong J. (2009). Externalizing behavior among adopted boys with preadoptive histories of child sexual abuse. Journal of Child Sexual Abuse, 18, 553-573.

Nazlı, S. (1997). Aile fonksiyonlarının bazı değişsenlere göre incelenmesi. Gazi Üniversitesi Eğitim Bilimleri Enstitüsü Eğitimde Psikolojik Hizmetler Anabilim Dalı yayınlanmamış doktora tezi.

Ogburn, W. F. (1963). Changing functions of the family, selected studies in marriage and the family. Rinehart and Winston Inc., U.S.A.

Orme, J. G., Cuddeback, G. S., Buehler, C., Cox, M. E., \& Le Prohn, N. S. (2007). Measuring foster parent potential: Casey foster parent inventory-applicant version. Research on Social Work Practice, 17 (1), 77-92.

Özgüven, İ. E. (2001). Ailede iletişim ve yaşam. PDREM yayınları, Ankara: Sistem Ofset.

Park, J., Turnbull, A. P., \& Turnbull III H. R. (2002). Impacts of poverty on quality of life in families of children with disabilities. Exceptional Children, 68(2), 151-170.

Pearlin, L. I., \& Schooler, C. (1978). The structure of coping. Journal of Health and SocialBehavior, 19, 2-21.

Purıla, S. (2006). Children with functional motor limitations: A three level approach. Printed Dissertation, Acta Universitatis Tamperensis 1131, ISBN 951-44-6506-7.

Pirıla, S., Meere, J. V. D., Seppanen, R. L., Ojala, L., Jaakkola, A., Korpela, R., \& Nieminen, P. (2005). Children with functional motor limitations: The effects on family strengths. Child Psychiatry and Human Development, 35(3), 281295. 
Rubin, L. B. (1994). Families on the fault line. New York: Harper Collins.

Sabatelli, R., Bartle, S. (1995). Survey Approaches to the Assessment of family functioning: Conceptual, operational, and analytical issues. Journal of Marriage and the Family, 57, 1025-1039.

Sanay, E. (1990). Türk ailesinin eğitim yapısı. T.C. Başbakanlık Aile Araştırma Kurumu Türkiye Yıllığı, 76.

Sertelin, Ç. (2003). Ebeveyn tutumlarının sosyo-kültürel yapı ve aile fonksiyonları ile ilişkisi. İstanbul Üniversitesi Sosyal Bilimler Enstitüsü Eğitim Bilimleri Anabilim Dalı yayınlanmamış yüksek lisans tezi. İstanbul.

Şimşek, H. B. (2009). Ankara'nın farklı sosyoekonomik bölgelerinde yaşayan aile bireylerinin aile ilişkilerini algılama durumları. Gazi Üniversitesi Endüstriyel Sanatlar Eğitim Fakültesi Dergisi, 25, 8-26.

Slee, P. T. (1996). Family climate and behavior in families with conduct disordered children. Child Psychiatry \& Human Development, 26, 255-266.

Straus, M. A., Gelles, R. J., \& Steinmetz, S. K. (1980). Behind closed doors: Violence in the American family. Garden City, NY: Anchor Press I Double day.

Sylvanus, U. J. (1992). Effects of early intervention on family functioning. Available from http://en.scientificcommons.org/8900263 [20 December 2011].

Voydanoff, P. (1984). Economic distress and families. Journal of Family Issues, 5, 273-288.

Wilkins, T. (2007). Towards conservations between families and professionals: What helps and hinders family coping when caring for a child with special needs. Trinity Western University, The Faculty of Graduate Studies, Graduate Counseling Psychology Program Master Thesis.

Yıldız, A. S. (1997). Çalışan evli bireylerin aile fonksiyonları ve iş tatmini düzeyleri arasındaki ilişkinin incelenmesi. Yayımlanmamış Yüksek Lisans Tezi, İstanbul Üniversitesi, Sosyal Bilimler Enstitüsü, İstanbul

Yorburg, B. (1983). Families and societies survival and extinction, Colombia University Pres: New York, U.S.A. 